\title{
The Relationship Between Esophageal Corrosion and Dynamic Thiol-Disulfide and Ischemia Modified Albumin Levels in Children
}

\author{
Çocuklarda Özefagus Korozyonu ile Dinamik Tiyol-Disülfid ve \\ İskemi Modifiye Albumin Düzeyleri Arasındaki İlişki
}

\author{
Can Ihsan OZTORUN, Gokhan DEMIRTAS², Sabri DEMIR², Dogus GUNEY¹, Rabia DEMIR ATA³, \\ Suleyman Arif BOSTANCl ${ }^{2}$, Ahmet ERTURK², Ali GUNGOR, Aysun KARA UZUN5, Gamze AVCIOGLU6, \\ Salim NESELIOGLU' ${ }^{\text {, Emrah SENEL }}{ }^{1}$
}

\author{
${ }^{1}$ Ankara Yildirim Beyazit University, School of Medicine, Department of Pediatric Surgery, Ankara, Turkey \\ ${ }^{2}$ Ankara City Hospital Children's Hospital, Department of Pediatric Surgery, Ankara, Turkey \\ ${ }^{3}$ Sirnak State Hospital, Department of Pediatric Surgery, Sırnak, Turkey \\ ${ }^{4}$ Ankara Dr. Sami Ulus Children's Hospital, Department of Pediatrics, Ankara, Turkey \\ ${ }^{5}$ Ankara City Hospital Children's Hospital, Department of Pediatrics, Ankara, Turkey \\ ${ }^{6}$ Ankara Yildirim Beyazit University, School of Medicine, Department of Biochemistry, Ankara, Turkey
}

\begin{abstract}
Objective: Corrosive burns of esophagus occurring in childhood has life-threatening complications. Its detection via biochemical substrates instead of performing esophagoscopy is crucially important for children. Determination of oxidative stress markers including thiol/disulfide homeostasis and ischemia modified albumin levels may provide valuable information for corrosive esophageal burns. The study aims to investigate the relation between esophageal corrosion and thiol/disulfide homeostasis and ischemia-modified albumin levels in children.
\end{abstract}

Material and Methods: Eighteen patients who underwent esophagoscopy due to corrosive substances intake (esophagoscopy group) and age and gender-matched 18 volunteers (control group) were included study. Blood levels of native thiol (-SH), total thiol (SH+SS), dynamic disulfide (SS), albumin and ischemia modified albumin (IMA) were measured in both groups. SPSS 17.0 was used for analyses and $p<0.05$ was considered significant.

Results: Laboratory results of cases with esophageal burn $(n=13)$ and without burn $(n=5)$ and control $(n=18)$ were compared. There was a significant decrease in levels of dynamic disulfide $(p=0.03)$, and dynamic disulfide/total thiol ratio $(\mathrm{p}=0.01)$ of children with esophageal burn compared with that of children with no burn or were found to be statistically significant.

Conclusion: Decreased levels of disulphide and dynamic disulfide/total thiol ratio would be used as a laboratory test to show corrosion in the esophagus. However, randomized, multicentric studies with larger samples are needed.

Key Words: Children, Corrosive esophageal burns, Ischemia Modified Albumin, Oxidative stress, Thiol/disulfide homeostasis

(10)

0000-0002-5408-2772: OZTORUN CI 0000-0003-0787-2330: DEMIRTAS G 0000-0003-4720-912X: DEMIR S O000-0001-7168-2123: GUNEYD O0000-0001-7079-2123: GUNE D 000-0002-7512-3895: BOSTANCI SA 0000-0002-8156-5665: ERTURK A 0000-0003-3508-5684: GUNGOR A D000-0002-1028-5949: KARA UZUN A 0000-0003-0819-528X: AVCIOGLU G 0000-0002-0974-5717: NESELIOGLUS 0000-0002-0383-4559: SENEL E
Conflict of Interest / Çıkar Çatışması: On behalf of all authors, the corresponding author states that there is no conflict of interest.

Ethics Committee Approval / Etik Kurul Onayr: This study was conducted in accordance with the Helsinki Declaration Principles. Approval of the Ethics Committee was taken from the ethics committee of Ankara Children Health and Diseases Hematology Oncology Training and Research Hospital (with decision number of 2017/02 dated with 27/03/2017)

Contribution of the Authors / Yazarların katkıs: OZTORUN CI: Constructing the hypothesis or idea of research and/or article, Planning methodology to reach the Conclusions, Taking responsibility in logical interpretation and conclusion of the results, Taking responsibility in the writing of the whole or important parts of the study, Reviewing the article before submission scientifically besides spelling and grammar. DEMIRTAS G: Organizing, supervising the course of progress and taking the responsibility of the research/study, Taking responsibility in necessary literature review for the study. DEMIR S: Organizing, supervising the course of progress and taking the responsibility of the research/study, Taking responsibility in necessary literature review for the study. GUNEY D: Planning methodology to reach the Conclusions, Taking responsibility in necessary literature review for the study. DEMIR ATA R: Organizing, supervising the course of progress and taking
the responsibility of the research/study. BOSTANCI SA: Taking responsibility in patient follow-up, collection of relevant biological materials, data management and the responsibility of the research/study. BOSTANCI SA: Taking responsibility in patient follow-up, collection of relevant biological materials, data management and
reporting, execution of the experiments. ERTURK A: responsibility in patient follow-up, collection of relevant biological materials, data management and reporting, execution of the experiments, Reviewing the article before submission scientifically besides spelling and grammar. GUNGOR A: Taking responsibility in necessary literature review for the study, Taking responsibility in the writing of the whole or important parts of the study. KARA UZUN A: Taking responsibility in patient followup, collection of relevant biological materials, data management and reporting, execution of the experiments. AVCIOGLU G: Taking responsibility in necessary literature review for the study, Taking responsibility in the writing of the whole or important parts of the study. NESELIOGLU S: Constructing the hypothesis or the study, Reviewing the article before submission scientifically besides spelling and grammar. SENEL E: Constructing the hypothesis or idea of research and/or article, Planning methodology to reach the Conclusions, Taking responsibility in the writing of the whole or important parts of the study, Reviewing the article before submission scientifically besides spelling and grammar.

How to cite / Atıf yazım sekli : Oztorun Cl, Demirtas G, Demir S, Guney D, Demir Ata R, Bostanci SA, et al. The Relationship Between Esophageal Corrosion and Dynamic Thiol-Disulfide and Ischemia Modified Albumin Levels in Children. Turkish J Pediatr Dis 202X;
Correspondence Address / Yazıșma Adresi:

Can Ihsan OZTORUN

Ankara Yildirim Beyazit University, School of Medicine,

Department of Pediatric Surgery, Ankara, Turkey

E-posta: drcan-oz@hotmail.com
Received / Geliş tarihi : :06.05.2021 Accepted / Kabul tarihi : 06.07.2021 Online published Elektronik yayın tarihi

DOI: 10.12956/tchd.933755 


\section{öz}

Amaç: Çocukluk çağında özoagusun korozif yanıkları hayatı tehdit eden ciddi bir durumdur. Çocuklarda korozif tanısı koymada özefagoskopi yapmak yerine biyokimyasal marker ile saptamak çok önemlidir. Oksidatif stres belirteçlerinden tiyol / disülfid homeostazı ve iskemi modifiye albümin seviyelerinin belirlenmesi, korozif özofagus yanıkları için tanısal bilgiler sağlayabilir. Çalışma, çocuklarda özofagus korozyonu ile tiyol / disülfid homeostazı ve iskemi modifiye albümin düzeyleri arasındaki ilişkiyi araştırmayı amaçlamaktır.

Gereç ve Yöntemler: Çalışmaya, korozif madde alımı nedeni ile özofagoskopi yapılan 18 hasta (özofagoskopi grubu) ve yaş ve cinsiyet uyumlu 18 gönüllü (kontrol grubu) dâhil edildi. Her iki grupta nativ tiyol (-SH), toplam tiyol (SH+SS), dinamik disülfid (SS), albümin ve iskemi modifiye albümin (IMA) kan seviyeleri ölçüldü. Analizler için SPSS 17.0 kullanıldı ve $p<0.05$ anlamlı kabul edildi.

Bulgular: Özofagus yanığı olan $(n=13)$ ve yanık olmayan $(n=5)$ olguların ve kontrol grubunun $(n=18)$ laboratuvar sonuçları karşlaştırıdı. Özofagus yanığı olan çocukların dinamik disülfid düzeylerinde $(p=0.03)$ ve dinamik disülfid / toplam tiyol oranında $(p=0.01)$ yanık olmayan çocuklara göre azalma görüldü veya istatistiksel olarak anlamlı bulundu.

Sonuç: Disülfid seviyesi ve dinamik disülfid / total tiyol oranının azalmasından dolayı özefagus korozyonu göstermek için bir laboratuvar testi olarak kullanılabilir. Ancak, çok merkezli, randomize, daha fazla örneklemli çalısmalara intiyaç vardır.

Anahtar Sözcükler: Çocuk, Korozif özofagus yanıkları, İskemi Modifiye Albümin, Oksidatif stres, Tiyol / disülfid dengesi

\section{INTRODUCTION}

Corrosive substances that are accidentally drunk in childhood may cause serious esophageal burns and life-threatening complications. Therefore, it is extremely important to diagnose and treat accurately. Therefore, it is extremely important to diagnose damage early and treat appropriately (1). Although there is a consensus that upper gastrointestinal endoscopy should be performed within the first 24 to 48 hours to determine the depth and extent of the burn and order the treatment according to these findings, in the asymptomatic cases, routine upper gastrointestinal endoscopic examination was found to be not useful and reported that accurate evaluation can be made by considering clinical and laboratory findings to estimate the degree of esophageal injury (2-7). Still there is no specific laboratory test to show burn formation in the esophagus. If there was a specific laboratory test indicating whether the esophagus was damaged, there would be no need for esophagoscopy in children after the ingestion of corrosive substances.

Biological damage caused by the harmful effects of free radicals is called oxidative stress. In the living organism, there is a very delicate balance between the production of free radicals and antioxidant-based defense mechanism (8). This balance is essential for the survival and state of health of living organisms (9). It is generally known that oxidative stress increases as a result of activation of neutrophils and macrophages and overproduction of free oxygen radicals in inflammatory events (1012). In the early period of corrosive esophageal injuries, reactive oxygen metabolites and activated neutrophils are thought to have important roles $(13,14)$. Production of reactive oxygen species (ROS) that occur in the first damage cause mechanical, pathological changes and cell signal changes in the affected organ. In one study, lipid peroxidation products remained high in corrosive esophageal burns for 72 hours at the highest level in the first 24 hours. According to this result, it has been suggested that esophagitis due to caustic damage may be related to free radicals (14).
Thiols, also known as mercaptans are compound that contains the functional group composed of a sulfur atom and a hydrogen atom $(-\mathrm{SH})(15,16)$. Plasma thiols have prooxidant or antioxidant effects on physiological events, but they are generally considered to be antioxidants. Whether the thiols will act as anti- or pro-oxidant will be determined by the concentration of oxidative stress, physiological conditions and the concentration of sulfur-containing amino acids (cysteine and methionine) in the medium. Prooxidant effects induced by thiol compounds have been reported in renal ischemia, liver failure, and diseases of the cardiovascular and cerebrovascular tissues. Via oxidative reactions, thiols (RSH) can form covalent disulfide bonds (RSSR). In oxidative stress, oxidation of cysteine residues may cause the formation of reversible mixed disulfides between protein thiol groups and low molecular weight thiols. These disulfide bonds can be reduced again to the thiols. Corrosive substances that are accidentally drunk in childhood may cause serious esophageal burns and life-threatening complications. Therefore, it is extremely important to diagnose and treat accurately.

Maintaining dynamic thiol-disulfide homeostasis plays a critical role in the regulation of antioxidant protection, detoxification, signal transduction, apoptosis, enzymatic activity, transcription factors, and cellular signaling mechanisms (12). In addition, it has been shown that the disturbances of the dynamic thioldisulfide homeostasis plays a role in the pathogenesis of many diseases such as diabetes, cardiovascular diseases, cancer, rheumatoid arthritis, chronic kidney disease, AIDS, Parkinson's disease, Alzheimer's disease, Friedrich ataxia, multiple sclerosis, amyotrophic lateral sclerosis and liver diseases (15). Therefore, the determination of dynamic thiol/disulfide homeostasis may provide valuable information about various normal or abnormal biochemical processes. Automatic measurement of plasma serum thiol/sulfide homeostasis by colorimetric method was made possible by a newly developed method (15).

IMA is an FDA-approved test among the newly investigated cardiac markers (17). The principle of the test is based on 
measuring the cobalt binding capacity of albumin, leading to chemical changes in the albumin during oxidation. This new albumin molecule is called ischemia-modified albumin. The formation of this new albumin molecule, which has lost its ability to cobalt, is one of the earliest markers of ischemia (18). However, recent studies suggest that IMA, which stands out as a marker of cardiac ischemia, may also increase in other pathologies (19-21).

The aim of this study is to investigate the relationship between esophageal corrosion and dynamic thiol-disulfide and ischemiamodified albumin levels in children and to find out whether there is a specific laboratory test in the esophagus.

\section{MATERIAL and METHOD}

Thirty-six volunteers children under the age of 15 were included in the study and divided into two groups as esophagoscopy group (EG) and control group (CG). A total of 18 patients included EG who had admitted pediatric surgery clinic in Ankara Children Health and Disease Hematology Oncology Training and Research Hospital for corrosive substances ingestion and underwent esophagoscopy, between 1st March 2017 and 1st September 2017. The CG was formed of 18 volunteers whose were similar in age and sex to EG, who applied for circumcision and inguinal hernia repair and had no other disease. The study was designed prospectively. Approval of the Ethics Committee was taken from the ethics committee of Ankara Children Health and Diseases Hematology Oncology Training and Research Hospital (with decision number of 2017/02 dated with 27/03/2017). An informed consent form was obtained from the parents of both groups included in the study. Esophagoscopic examination was performed with rigid esophagoscope in all patients.

Two $\mathrm{mL}$ of venous blood sample was taken from the patients undergoing esophagoscopy, into the yellow-capped gel tubes (BD Vacutainer plastic SST II tube ${ }^{\circledR}$ ) 1-2 hours before performing esophagoscopy and 24 hours after the procedure. Blood samples were taken from the volunteers in the CG when preoperative tests were performed. All samples were centrifuged for 10 minutes at $3600 \mathrm{rpm}$ in the biochemistry laboratory and two $\mathrm{mLserum}$ were obtained. Serum samples were stored at $-80^{\circ} \mathrm{C}$. After all the samples were collected, all of them were thawed at the same time and the blood thiol-disulfide homeostasis parameters were determined by automatic measurement method invented by Erel and Neselioglu (15) and IMA levels were determined by Bar-Or et al. (22) within Roche Hitachi Cobas c501 automatic analyzer. The levels of native thiol (-SH), total thiol (SH+SS), dynamic disulfide (SS), albumin and ischemic modified albumin (IMA) were measured. The study flow diagram was shown in Figure 1.

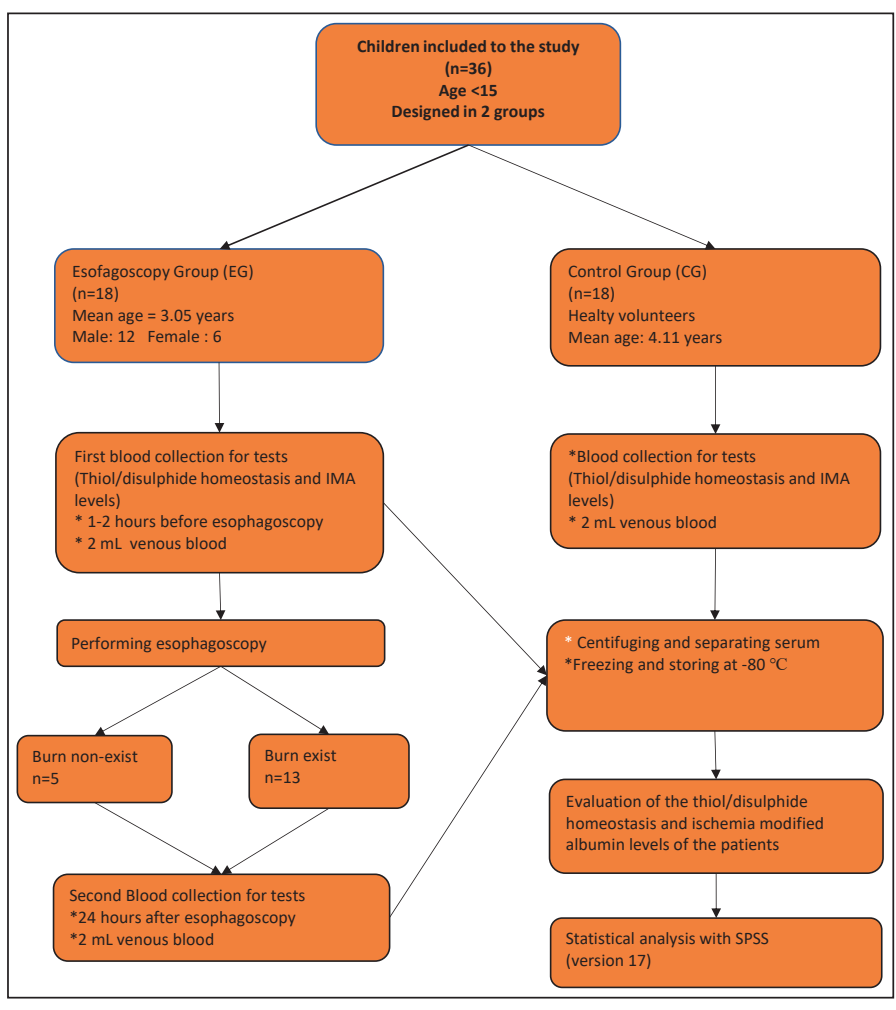

Figure 1: Flow diagram of the study.

\section{Statistical analysis}

Statistical analysis was performed using Statistical Package for Social Sciences (SPSS) software (version 16, SPSS, Inc, Chicago, IL, USA). Normal distribution of the continuous variables were tested via visual variables (histogram and probability graphs) and analytical methods (Shapiro-Wilk test). While the native thiol $(\mathrm{SH})$, total thiol, albumin values of the groups were found to have normal distribution, IMA, dynamic disulfide (SS) and percentage of dynamic disulfide (SS)/total thiol $(\mathrm{SS}+\mathrm{SH})$ values did not fit the normal distribution. Normally distributed variables were analyzed by One-Way ANOVA test whereas variables which did not was analyzed by KruskalWallis H Test. Dynamic disulphide (SS), native thiol, total thiol, percentage of dynamic disulfide (SS)/total thiol (SS+SH), IMA and albumin values were analyzed by paired correlation test in the patient group. $p<0.05$ was considered as significant.

\section{RESULTS}

In the study, 18 cases who underwent esophagoscopy due to corrosive substance ingestion were evaluated and their data were compared with control group.

The mean age of the CG was 4.11 years with standard deviation of 1.93 (range: $1-7$ years) and it was 3.05 years in $E G$ with standard deviation of 1.79 (range: 1-7 years). There was similarity between groups in terms of age $(p=0.62)$ (Table I). 
Table I: Demographics of esophagoscopy and control groups.

\begin{tabular}{l|c|c|c|}
\hline & $\begin{array}{c}\text { Esophagoscopy } \\
\text { group } \\
\mathbf{n = 1 8}\end{array}$ & $\begin{array}{c}\text { Control group } \\
\mathbf{n = 1 8}\end{array}$ & $\begin{array}{c}\text { Student t } \\
\mathbf{p}\end{array}$ \\
\hline $\begin{array}{l}\text { Gender (n), } \\
\text { Male/Female }\end{array}$ & $12 / 6$ & $12 / 6$ & \\
\hline $\begin{array}{l}\text { Age (years), } \\
\text { Mean (SD), } \\
\text { min-max }\end{array}$ & $3.05(1.79), 1-7$ & $4.11(1.93), 1-7$ & 0.62 \\
\hline
\end{tabular}

Table II: The distribution of the burn degrees seen in rigid esophagoscopy.

\begin{tabular}{l|l}
\multicolumn{1}{c}{ Burn degree } & $\mathbf{n}$ \\
\hline None (burn negative) & 5 \\
Grade 1 & 3 \\
Grade 2a & 6 \\
Grade 2b & 2 \\
Grade 3 & 2 \\
\hline
\end{tabular}

n: frequency, SD: standard deviation, min-max: minimum-maximum

Table III: The comparisons of laboratory variables among three groups.

\begin{tabular}{|c|c|c|c|c|c|c|c|}
\hline Variables & Group & $\mathbf{n}$ & Mean & Median & SD & Min-Max & $\mathbf{p}$ \\
\hline \multirow{3}{*}{ Native thiol (SH) } & Burn (+) & 13 & 391.3231 & 393.0000 & 44.92769 & $327.50-467.10$ & \multirow{3}{*}{$0.553^{\star}$} \\
\hline & Burn (-) & 5 & 400.4600 & 399.2000 & 23.19317 & $375.50-438.10$ & \\
\hline & Control & 18 & 407.5500 & 393.5500 & 40.63690 & $339.80-525.70$ & \\
\hline \multirow[t]{2}{*}{ Total thiol $(\mathrm{SH}+\mathrm{SS})$} & Burn (-) & 5 & 439.7200 & 447.1000 & 34.33689 & $403.50-479.00$ & \multirow[t]{2}{*}{$0.299^{*}$} \\
\hline & Control & 18 & 448.0444 & 444.4000 & 43.96178 & $373.90-525.70$ & \\
\hline \multirow{2}{*}{ Disulfide (SS) } & Burn (+) & 13 & 15.0769 & 15.0000 & 7.60988 & $2.00-31.00$ & \multirow{2}{*}{$0.037^{\dagger}$} \\
\hline & Control & 18 & 20.2222 & 18.0000 & 3.76603 & $16.00-28.00$ & \\
\hline \multirow{3}{*}{ Disulfide/ Total Thiol, \% } & Burn (+) & 13 & 3.5079 & 3.3905 & 1.73705 & $0.60-7.94$ & \multirow{3}{*}{$0.018^{\dagger}$} \\
\hline & Burn (-) & 5 & 4.3534 & 4.1754 & 2.49358 & $0.74-6.90$ & \\
\hline & Control & 18 & 4.5142 & 4.3599 & 0.71 & $3.47-6.19$ & \\
\hline \multirow[b]{2}{*}{ Ischemia modified albumin } & Burn (+) & 13 & 0.6493 & 0.6750 & 0.09457 & $0.38-0.74$ & \multirow[b]{2}{*}{$0.477^{\dagger}$} \\
\hline & Burn (-) & 5 & 0.7024 & 0.6930 & 0.03357 & $0.67-0.75$ & \\
\hline
\end{tabular}

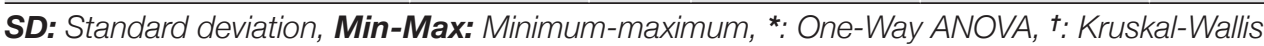

Table IV: Pre-op and post-operative 24 hours laboratory findings of cases with esophageal burn.

\begin{tabular}{|c|c|c|c|c|}
\hline Variables & Mean & Std. Deviation & Std. Error & $p^{*}$ \\
\hline IMA (pre-op) & 0.6906 & 0.01936 & 0.00732 & \multirow{2}{*}{0.144} \\
\hline IMA (post-op 24 hours) & 0.7206 & 0.04500 & 0.01701 & \\
\hline Albumin (pre-op) & 4.2857 & 0.26095 & 0.09863 & \multirow[b]{2}{*}{0.111} \\
\hline Albumin (post-op 24 hours) & 4.3857 & 0.25448 & 0.09619 & \\
\hline Native thiol (pre-op) & 381.2143 & 40.89435 & 15.45661 & \multirow[t]{2}{*}{0.693} \\
\hline Native thiol (post-op 24 hours) & 391.3857 & 39.34596 & 14.87138 & \\
\hline Total thiol (pre-op) & 411.4286 & 38.59938 & 14.58920 & \multirow[t]{2}{*}{0.594} \\
\hline Total thiol (post-op 24 hours) & 424.9714 & 46.44358 & 17.55402 & \\
\hline Disulfide (pre-op) & 14.8571 & 7.62515 & 2.88203 & \multirow[t]{2}{*}{0.440} \\
\hline Disulphide (post-op 24 hours) & 16.8571 & 5.66947 & 2.14286 & \\
\hline Disulfide/Total thiol, \% (pre-op) & 3.6295 & 1.95842 & 0.74021 & \multirow[t]{2}{*}{0.685} \\
\hline Disulfide/Total thiol, \% (post-op) & 3.9220 & 1.11106 & 0.41994 & \\
\hline
\end{tabular}

Std: Standard, IMA: Ischemia modified albumin, *: paired sample test

The distribution of patients according to the degree of burns seen in esophagoscopy was shown in Table II.

The patients of EG were divided into two groups as burn negative $(n=5)$ and burn positive $(n=13)$ and their ischemia-modified albumin (IMA), albumin, native thiol $(\mathrm{SH})$, total thiol $(\mathrm{SH}+\mathrm{SS})$, dynamic disulfide (SS), percentage of dynamic disulfide (SS)/ total thiol $(\mathrm{SH}+\mathrm{SS})$ levels were compared with that of $\mathrm{CG}(\mathrm{n}=18)$ and shown in Table III.

There was a decrease in levels of native thiol $(p=0.55)$, total thiol $(p=0.29)$, dynamic disulfide $(p=0.03)$, percentage of dynamic disulfide/total thiol ( $p=0.01)$, IMA $(p=0.47)$ and albumin $(p=0.75)$ of children with esophageal burn compared to that of children 
with had not burn or with control, and decrease in dynamic disulfide and dynamic disulfide / total thiol ratio were found to be statistically significant (Kruskal-Wallis test).

The comparison of laboratory results in children with esophageal burn before and after esophagoscopy was shown in Table IV. There were no statistical differences between the results of patients before esophagoscopy and after 24 hours, in terms of native thiol, total thiol, dynamic disulfide, \% dynamic disulfide/ total thiol, albumin and IMA levels (p>0.05).

\section{DISCUSSION}

Serious complications such as esophageal strictures or perforations can develop as a result of esophageal burns caused by the ingestion of corrosive substances in childhood. Therefore, early and accurately diagnosis and initiation of proper treatment are crucial in these patients. The necessity of endoscopy is controversial in children with suspicion of corrosive substance ingestion especially in patients without signs and symptoms. Studies related to this issue suggest that esophagoscopy is the preferred method to determine the degree of esophageal injury and to prevent the formation of corrosive stricture and to accurately select patients for initiating treatment, and it has also been suggested that assessment of injury by esophagoscopy constitutes the basis of the treatment plan $(23,24)$. In contrast, especially in developed countries, there are those who argue that clinical follow-up and laboratory findings may predict the degree of injury and that esophagoscopy should not be performed to each patient (5). However, some authors suggest that the absence of clinical symptoms cannot rule out esophageal burns $(5,7)$.

By now, there is no specific laboratory test for the diagnosis of esophageal burns due to corrosive substance ingestion in children. Several studies were pointed out the relationship between oxidative stress markers and a different spectrum of diseases. However, there is no study regarding the relation between esophageal corrosion and oxidative stress in children. This study is the very first to show the relationship between esophageal corrosion and thiol-disulfide and IMA levels in children.

In our study, dynamic disulfide and percentage of dynamic disulfide/total thiol levels were found to be significantly low in children with esophageal burn compared to children without burn or controls. Although a decrease in total and native thiol levels of patients with burns was also detected in two groups, there was no statistically significant difference. Albumin and IMA levels of the cases with burns were found to be low compared to that of children without burn or controls, but there was no statistical significance. These results suggest that disruption of the thiol-disulfide homeostasis in children may be a laboratory test indicating possible damage in esophageal corrosion, but IMA will not have a suitable laboratory finding to demonstrate esophageal injury.
This study has some limitations which have to be pointed out. The number of patients included in our study was low and the study was not randomized. Studies involving large numbers of patients and randomization are needed to confirm the effectiveness of the test.

\section{CONCLUSION}

It is tough to diagnose esophageal burns due to ingestion corrosive substances in children without esophagoscopy. Since there is no spesific test for diagnosis, esophagoscopy is performed in all suspicious cases. Invention of a specific laboratory test to diagnose the esophagus burn will prevent unnecessary esophagoscopy and reduce the complications associated with the procedure and the length of hospital stay. In our study, it is shown that the disturbing in the balance of thiol-disulfide homeostasis, which is an indicator of increased oxidative stress, can be used as a laboratory finding to show corrosion in the diagnosis of esophageal burns as a result of corrosive substance ingestion. However, due to the small number of patients in our study, randomized, multicentric studies with larger samples are needed.

\section{What is already known?}

There is no specific, non-invasive laboratory test for diagnosis in children who ingest corrosive substance.

\section{What this study adds?}

The evaluation of disturbing in the balance of thiol-disulfide homeostasis can be used as a laboratory finding to show corrosion in the diagnosis of esophageal burns as a result of corrosive substance ingestion.

\section{REFERENCES}

1. de Jong AL, Macdonald R, Ein S, Forte V, Turner A. Corrosive esophagitis in children: a 30-year review. Int $\mathrm{J}$ Pediatr Otorhinolaryngol 2001;57:203-11.

2. Huang YC, Ni YH, Lai HS, Chang $\mathrm{MH}$. Corrosive esophagitis in children. Pediatr Surg Int 2004;20:207-10.

3. Chiu HM, Lin JT, Huang SP, Chen CH, Yang CS, Wang HP. Prediction of bleeding and stricture formation after corrosive ingestion by EUS concurrent with upper endoscopy. Gastrointest Endosc 2004;60:827-33.

4. Boskovic A, Stankovic I. Predictability of gastroesophageal caustic injury from clinical findings: is endoscopy mandatory in children? Eur J Gastroenterol Hepatol 2014;26:499-503.

5. Betalli P, Falchetti D, Giuliani S, Pane A, Dall'Oglio L, de Angelis $\mathrm{GL}$, et al. Caustic ingestion in children: is endoscopy always indicated? The results of an Italian multicenter observational study. Gastrointest Endosc 2008;68:434-9.

6. GuptaSK,CroffieJM, FitzgeraldJF.Isesophagogastroduodenoscopy necessary in all caustic ingestions? J Pediatr Gastroenterol Nutr 2001;32:50-3. 
7. Havanond C, Havanond P: Initial signs and symptoms as prognostic indicators of severe gastrointestinal tract injury due to corrosive ingestion. J Emerg Med 2007;33:349-53.

8. Saugstad OD. Mechanisms of tissue injury by oxygen radicals: implications for neonatal disease. Acta Paediatr 1996;85:1-4.

9. Valko M, Leibfritz D, Moncol J, Cronin MT, Mazur M, Telser J. Free radicals and antioxidants in normal physiological functions and human disease. Int J Biochem Cell Biol 2007;39:44-84.

10. Bolukbas C, Bolukbas FF, Horoz M, Aslan M, Celik H, Erel O. Increased oxidative stress associated with the severity of the liver disease in various forms of hepatitis B virus infection. BMC Infect Dis 2005;5:95. https://doi.org/10.1186/1471-2334-5-95.

11. Ozdogan M, Devay AO, Gurer A, Ersoy E, Devay SD, Kulacoglu $\mathrm{H}$, et al. Plasma total anti-oxidant capacity correlates inversely with the extent of acute appendicitis: a case control study. World J Emerg Surg 2006;1:6. https://doi.org/10.1186/1749-7922-1-6.

12. Serefhanoglu K, Taskin A, Turan H, Timurkaynak FE, Arslan H, Erel O. Evaluation of oxidative status in patients with brucellosis. Braz J Infect Dis 2009;13:249-51.

13. Ozel SK, Dagli TE, Yuksel M, Kiyan G, Kotiloglu E. The roles of free oxygen radicals, nitric oxide, and endothelin in caustic injury of rat esophagus. J Pediatr Surg 2004;39:1381-5.

14. Gunel E, Caglayan F, Caglayan O, Akillioglu I. Reactive oxygen radical levels in caustic esophageal burns. J Pediatr Surg 1999;34:405-7

15. Erel O, Neselioglu S. A novel and automated assay for thiol/ disulphide homeostasis. Clin Biochem 2014;47:326-32.
16. Sen $C K$, Packer $L$. Thiol homeostasis and supplements in physical exercise. Am J Clin Nutr 2000;72:653S-69S.

17. Wudkowska A, Goch J, Goch A. Ischemia-modified albumin in differential diagnosis of acute coronary syndrome without ST elevation and unstable angina pectoris. Kardiol Pol 2010;68:431-7.

18. Aran T, Unsal MA, Guven S, Kart C, Cetin EC, Alver A. Carbon dioxide pneumoperitoneum induces systemic oxidative stress: a clinical study. Eur J Obstet Gynecol Reprod Biol 2012;161:80-3.

19. Ma SG, Wei CL, Hong B, Yu WN. Ischemia-modified albumin in type 2 diabetic patients with and without peripheral arterial disease. Clinics (Sao Paulo) 2011;66:1677-80.

20. Mastella AK, Moresco RN, da Silva DB, Becker AM, Duarte MM, Giovelli LL, et al. Evaluation of ischemia-modified albumin in myocardial infarction and prostatic diseases. Biomed Pharmacother 2009;63:762-6.

21. Lippi G, Montagnana M. Ischemia-modified albumin in ischemic disorders. Ann Thorac Cardiovasc Surg 2009;15:137.

22. Bar-Or D, Lau E, Winkler JV. A novel assay for cobalt-albumin binding and its potential as a marker for myocardial ischemia-a preliminary report. J Emerg Med 2000;19:311-5.

23. Gaudreault P, Parent M, McGuigan MA, Chicoine L, Lovejoy FH, Jr. Predictability of esophageal injury from signs and symptoms: a study of caustic ingestion in 378 children. Pediatrics 1983;71:76770.

24. Temiz A, Oguzkurt P, Ezer SS, Ince E, Hicsonmez A. Predictability of outcome of caustic ingestion by esophagogastroduodenoscopy in children. World J Gastroenterol 2012;18:1098-103. 